\title{
Size at Morphological Maturity of Ucides cordatus (Linnaeus, 1763) (Brachyura, Ocypodidae) in the Laranjeiras Bay, Southern Brazil
}

\author{
Glaucia Dalabona $^{1 *}$, Jayme de Loyola e Silva ${ }^{1}$ and Marcelo Antonio Amaro Pinheiro ${ }^{2}$ \\ ${ }^{1}$ Universidade Federal do Paraná; Setor de Ciências Biológicas; Departamento de Zoologia; C.P. 19020; \\ 81.531-990; gdalabona@yahoo.com.br; Curitiba - PR - Brazil. ${ }^{2}$ UNESP São Vicente; CRUSTA; Departamento de \\ Biologia Marinha e Gerenciamento Costeiro; Pç. Infante D. Henrique, s/n; 11.330-900; São Vicente - SP - Brazil.
}

\begin{abstract}
Morphometry and maturity of Ucides cordatus were analyzed with males and females collected during one year on a monthly basis at Laranjeiras Bay, Paraná State, Brazil. Carapace length, chelipeds propodus length and abdominal width were measured and related to carapace width to verify sexual dimorphism and size at morphological maturity of each sex. Carapace and propodus length of larger and smaller cheliped presented difference between sexes, confirming the use of both as secondary sexual characters. MATURE II program indicated $44 \mathrm{~mm}$ and $43 \mathrm{~mm}$ of carapace width to represent the size at sexual maturity of males and females, respectively.
\end{abstract}

Key words: Reproduction, relative growth, fishery resource

\section{INTRODUCTION}

Stepped growth of crustaceans and differences observed between the sexes and the developing phases (juvenile and adult) allow the use of morphometric data to identify sexual dimorphism and the estimation of the maturity size. The regression model usually used for this purpose has been the function power $y=a x^{b}$ (Huxley, 1950), also known as the allometric growth equation, where the constant "b" indicates the growth pattern.

Crab Ucides cordatus (Linnaeus, 1763) is one of the commonest species in the mangrove ecosystem of the Western Atlantic (Costa, 1979), proving to be of great economic importance for capture and consumption in different regions, especially in
Northern-Northeastern Brazil (Fausto-Filho, 1968; IBAMA, 1994). Studies on relative growth for this species have been done only in relation to the carapace length (Alcântara-Filho, 1978; Castro, 1986; Branco, 1993), contrasting with studies carried out on other commercially explored Brachyura, such as the Portunidae (Davidson and Marsden, 1987; Haefner, 1990; Sumpton, 1990; Pinheiro and Fransozo, 1993; Gonzáles-Gurriarán and Freire, 1994; Knuckey, 1996; Pinheiro and Fransozo, 1998) and Majidae (Somerton, 1981; Conan and Comeau, 1986; Comeau and Conan, 1992; Paul and Paul, 1995; Sampedro et al., 1999), where a larger number of relationships were analyzed. Relative growth and size at maturity are very important aspects for the better understanding of the Brachyura reproductive process. It enables,

* Author for correspondence 
through estimate the minimum size for capture, the maintenance of viable population stocks for sale or for the species conservation. The purpose of this work was to establish sizes of morphologic maturity for male and female $U$. cordatus by analyzing the relative growth rate of the biometric relationships of the carapace, cheliped and the females' abdomen during ontogeny, as well as verifying indications of sexual dimorphism for this species.

\section{MATERIALS AND METHODS}

Monthly collections were carried out from September 1999 to August 2000 at Pavoçá and Peças islands situated at Laranjeiras Bay $\left(25^{\circ} 28^{\prime} \mathrm{S}\right.$ and $48^{\circ} 16^{\prime} \mathrm{W}$ ), State of Paraná, Brazil. Specimens were manually taken out of their galleries, placed in plastic bags and kept frozen until analyses time. An additional sample of 68 specimens (26 females and 42 males) was also collected in December 2000 to augment the number of the individuals analyzed. After being defrosted at room temperature, each specimen was measured with vernier calipers $(0.05 \mathrm{~mm})$ for records of carapace width $(\mathrm{CW})$, carapace length (CL) and larger cheliped's propodus length $\left(\mathrm{PL}_{\mathrm{lg}}\right)$ and smaller $\left(\mathrm{PL}_{\mathrm{sm}}\right)$. Females also had their fifth abdominal somite width measured (AW), which was not performed on males because of the irrelevance of this relationship for this sex (Pinheiro and Fransozo, 1993).

In order to analyze relative growth and maturity, procedures used by Pinheiro and Fransozo (1993 and 1998) were respectively adopted. The empirical points of the relationships $C L \times C W$, $\mathrm{PL}_{\mathrm{gg}} \times \mathrm{CW}$ and $\mathrm{PL}_{\mathrm{sm}} \times \mathrm{CW}$ and $\mathrm{AW} \times \mathrm{CW}$ were submitted to the regression analysis, with adjustment by the minimum squares method. To verify whether these relationships must be adjusted by more than one regression line, the MATURE program (Somerton, 1980; Somerton and Macintosh, 1983), which employs the Snedecor "F" test for this purpose, was used. The validation of two equations for one relationship indicates a difference in the growth rate during juvenile and adult phases, being the intercept between them correspondent to the size in puberty (or morphologic maturity size). Test " $\mathrm{t}$ " was applied to verify whether the declivity of regressions (constant "b") presented a significant difference of 1 , indicating the type of growth: isometric $(b=1)$, positive allometric $(b>1)$ or negative allometric $(b<1)$. In all cases a statistic significance of $5 \%$ was adopted.

\section{RESULTS}

A total of 555 specimens (232 females and 323 males) were used for the analyses for which the minimum, maximum, mean and standard deviation values of the biometric variables presented in Table 1. In Table 2 are the equations obtained for the biometric relationships for each sex and/or developing phase, according to the adjustment tests of the function power and validation of the allometry level. The relationships $\mathrm{CL} \times \mathrm{CW}, \mathrm{PL}_{\mathrm{g}} \mathrm{x}$ $\mathrm{CW}$ and $\mathrm{PL}_{\mathrm{sm}} \mathrm{x} C \mathrm{CW}$ best exemplified the species sexual dimorphism.

For females, the CL growth was isometric in relation to the $\mathrm{CW} \quad(\mathrm{b}=0.99)$, causing $\mathrm{a}$ proportional growth between these variables, while for males it was negative allometric $(b=0.93)$, showing a smaller growth rate for $C L$ (Fig. 1).

Table 1 - Ucides cordatus (Linnaeus, 1763). Summary statistics of the measured biometric variables for males and females $(\mathrm{N}=$ number of animals; Min. = minimum value; Max. = maximum value; $\overline{\mathrm{x}}=\mathrm{mean} ; \mathrm{SD}=\mathrm{standard}$ deviation; $\mathrm{CW}=$ carapace width; $\mathrm{CL}=$ carapace length; $\mathrm{PL}_{\mathrm{lg}}=$ larger cheliped propodus length; $\mathrm{PL}_{\mathrm{sm}}=\mathrm{smaller}$ cheliped propodus length; AW = abdomen width). All the variables are represented in millimeters.

\begin{tabular}{|c|c|c|c|c|c|c|c|c|}
\hline \multirow{2}{*}{ Biometric variables } & \multicolumn{4}{|c|}{ Males } & \multicolumn{4}{|c|}{ Females } \\
\hline & $\mathbf{N}$ & Min. & Max. & $\overline{\mathbf{x}}+\mathrm{SD}$ & $\mathbf{N}$ & Min. & Max. & $\overline{\mathbf{x}}+\mathrm{SD}$ \\
\hline $\mathrm{CW}$ & 323 & 35,5 & 83,5 & $59,9 \pm 10,8$ & 232 & 30,6 & 73,3 & $50,7 \pm 7,4$ \\
\hline $\mathrm{CL}$ & 323 & 27,8 & 63,1 & $46,1 \pm 7,8$ & 232 & 29,0 & 58,5 & $42,5 \pm 5,1$ \\
\hline $\mathrm{PL}_{\mathrm{lg}}$ & 323 & 26,2 & 89,9 & $57,5 \pm 15,4$ & 232 & 18,3 & 55,3 & $37,6 \pm 6,7$ \\
\hline $\mathrm{PL}_{\mathrm{sm}}$ & 323 & 18,7 & 58,4 & $37,0 \pm 9,1$ & 232 & 16,2 & 40,6 & $27,6 \pm 4,3$ \\
\hline AW & - & - & - & - & 126 & 15,5 & 42,8 & $29,9 \pm 5,5$ \\
\hline
\end{tabular}


Table 2 - Ucides cordatus (Linnaeus, 1763). Regression analyses for the biometric relationships (CW = carapace width; $\mathrm{CL}=$ carapace length; $\mathrm{PL}_{\mathrm{lg}}=$ larger cheliped propodus length; $\mathrm{PL}_{\mathrm{sm}}=$ smaller cheliped propodus length; $\mathrm{AW}$ $=$ abdomen width), obtained for each sex/category $(\mathrm{JM}=$ juvenile males; $\mathrm{AM}=$ adult males; $\mathrm{TM}=$ total of males; $\mathrm{JF}$ $=$ juvenile females; $\mathrm{AF}=$ adult females; $\mathrm{TF}=$ total of females $)$ and their allometry level $(0=$ isometry; $+=$ positive allometry; - = negative allometry).

\begin{tabular}{|c|c|c|c|c|c|c|c|}
\hline $\begin{array}{l}\text { Biometric } \\
\text { relationship }\end{array}$ & $\begin{array}{c}\text { Sex / } \\
\text { Category }\end{array}$ & $\mathbf{N}$ & $\begin{array}{l}\text { Power function } \\
\qquad\left(\mathbf{y}=\mathbf{a} \mathbf{x}^{\mathbf{b}}\right)\end{array}$ & $\begin{array}{l}\text { Linearized equation } \\
\quad(\ln y=\ln a+b \ln x)\end{array}$ & $\begin{array}{c}\mathbf{r}^{2} \\
(\%)\end{array}$ & $t$ test & $\begin{array}{c}\text { Allometry } \\
\text { level }\end{array}$ \\
\hline \multirow[t]{2}{*}{$\mathrm{CL} \times \mathrm{CW}$} & TM & 323 & $\mathrm{CL}=1,0181 \mathrm{CW}^{0,93}$ & $\mathrm{LnCL}=0,02+0,93 \ln \mathrm{CW}$ & 99 & $14,00 *$ & - \\
\hline & $\mathrm{TF}$ & 232 & $\mathrm{CL}=0,8071 \mathrm{CW}^{0,99}$ & $\operatorname{lnCL}=-0,21+0,99 \ln C W$ & 98 & $1,25 \mathrm{~ns}$ & 0 \\
\hline \multirow[t]{3}{*}{$\mathrm{PL}_{\lg } \times \mathrm{CW}$} & $\mathrm{JM}$ & 35 & $\mathrm{PL}_{\mathrm{lg}}=0,4148 \mathrm{CW}^{1,17}$ & $\mathrm{LnPL}_{\mathrm{lg}}=-0,88+1,17 \operatorname{lnCW}$ & 78 & $1,60 \mathrm{~ns}$ & 0 \\
\hline & $\mathrm{AM}$ & 288 & $\mathrm{PL}_{\mathrm{lg}}=0,1023 \mathrm{CW}^{1,54}$ & $\mathrm{LnPL}_{\mathrm{gg}}=-2,28+1,54 \operatorname{lnCW}$ & 94 & $25,39 *$ & + \\
\hline & $\mathrm{TF}$ & 232 & $\mathrm{PL}_{\mathrm{lg}}=0,3734 \mathrm{CW}^{1,17}$ & $\mathrm{LnPL}_{\mathrm{lg}}=-0,99+1,17 \mathrm{lnCW}$ & 88 & $6,09 *$ & + \\
\hline \multirow[t]{2}{*}{$\mathrm{PL}_{\mathrm{sm}} \times \mathrm{CW}$} & $\mathrm{TM}$ & 323 & $\mathrm{PL}_{\mathrm{sm}}=0,1549 \mathrm{CW}^{1,34}$ & $\mathrm{LnPL}_{\mathrm{sm}}=-1,87+1,34 \operatorname{lnCW}$ & 97 & $25,65 *$ & + \\
\hline & $\mathrm{TF}$ & 232 & $\mathrm{PL}_{\mathrm{sm}}=0,5426 \mathrm{CW}^{1,00}$ & $\mathrm{LnPL}_{\mathrm{sm}}=-0,61+1,00 \operatorname{lnCW}$ & 85 & $0,00 \mathrm{~ns}$ & 0 \\
\hline \multirow[t]{2}{*}{$\mathrm{AW} \times \mathrm{CW}$} & $\mathrm{JF}$ & 25 & $\mathrm{AW}=0,0302 \mathrm{CW}^{1,80}$ & $\ln \mathrm{AW}=-3,50+1,80 \operatorname{lnCW}$ & 89 & $5,96 *$ & + \\
\hline & $\mathrm{AF}$ & 101 & $\mathrm{AW}=0,5265 \mathrm{CW}^{1,04}$ & $\ln A W=-0,64+1,04 \operatorname{lnCW}$ & 90 & $1,04 \mathrm{~ns}$ & 0 \\
\hline
\end{tabular}

*: $p<0,05 ; \mathrm{ns}: p>0,05$
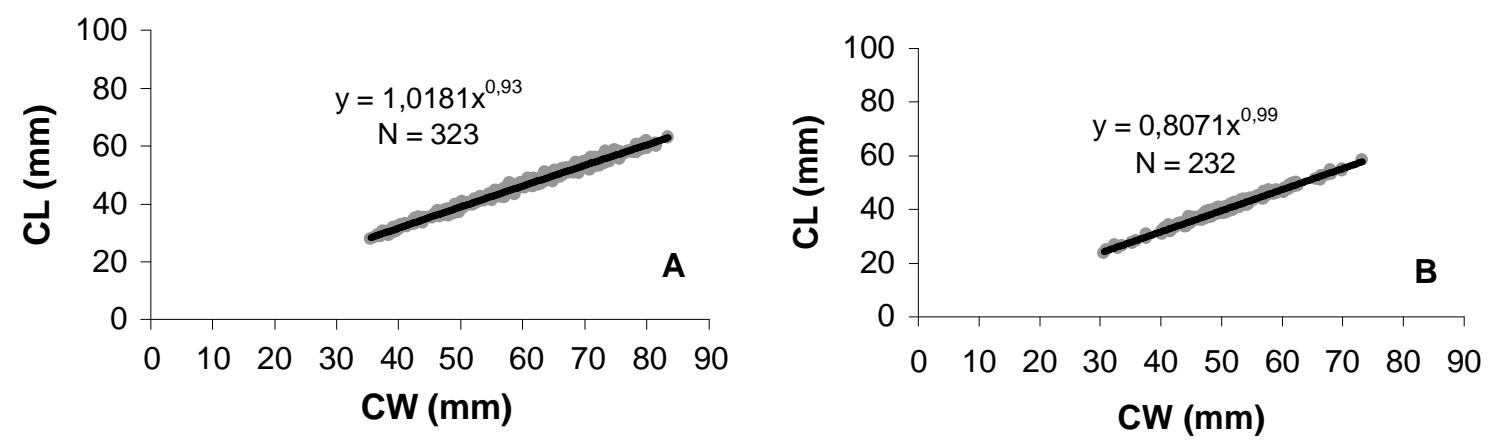

Figure 1 - Ucides cordatus (Linnaeus, 1763). Dispersion graph for the biometric relationship between carapace length $(\mathrm{CL})$ and carapace width $(\mathrm{CW})$, with their respective relative growth equations ( $\mathrm{A}=$ males; $\mathrm{B}=$ females).

The relationship $\mathrm{PL}_{\lg } \mathrm{x} \mathrm{CW}$ (Fig. 2) evidenced a positive allometric growth for females $(b=1.17)$ and adult males $(\mathrm{b}=1.54)$, showing a higher degree when compared with the smaller cheliped (PLsm). For males, the positive allometric growth of the variable $\mathrm{PL}_{\mathrm{lg}}$ was pronounced in the adult phase, contrasting with the juvenile phase where it was isometric. For the relationship $\mathrm{PL}_{\mathrm{sm}} \times \mathrm{CW}$ (Fig. 3) the females' growth was isometric $(b=1.00)$, although it was positive allometric for the males' $(\mathrm{b}=1.34)$. The relationship AW x CW (Fig. 4) showed be distinct between development phases of the females: strongly positive allometric in the juvenile phase $(b=1,80)$ and isometric at the adult phase $(b=1.04)$.

The MATURE II program was the most suitable for showing changes in the growth rate during the ontogeny of $U$. cordatus, which was confirmed only in the relationships $\mathrm{PL}_{\mathrm{lg}} \mathrm{x} \mathrm{CW}$ (males) and $\mathrm{AW} \times \mathrm{CW}$ (females). In these, the interception point between the obtained equations occurred with $44 \mathrm{~mm}$ for males $(\mathrm{F}=4.70 ; \mathrm{p}<0.05)$ and $43 \mathrm{~mm}$ for females $(\mathrm{F}=25.51 ; \mathrm{p}<0.05)$. For the other relationships, the values of " $F$ " were not significant, being therefore represented by only one equation for each sex. 

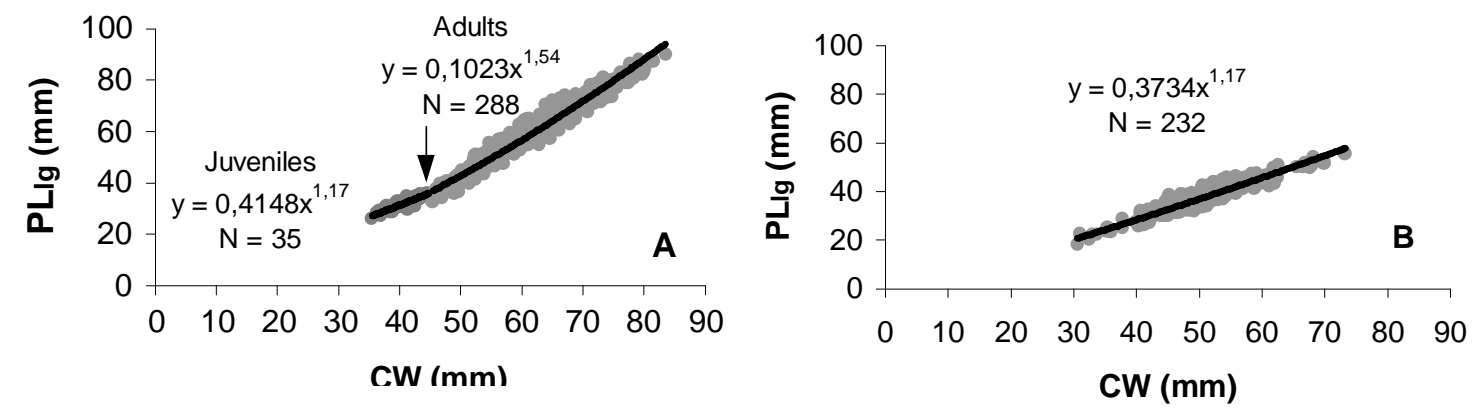

Figure 2 - Ucides cordatus (Linnaeus, 1763). Dispersion graph for the biometric relationship between larger cheliped propodus length $\left(\mathrm{PL}_{\mathrm{lg}}\right)$ and carapace width $(\mathrm{CW})$, with their respective relative growth equations ( $\mathrm{A}=$ males; $\mathrm{B}=$ females).
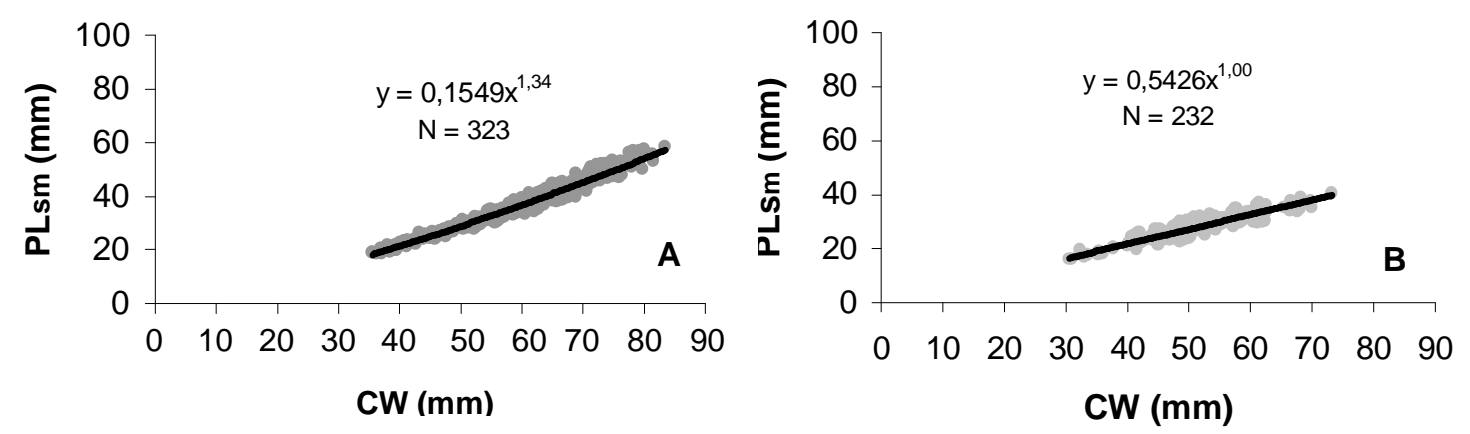

Figure 3 - Ucides cordatus (Linnaeus, 1763). Dispersion graph for the biometric relationship between smaller cheliped propodus length $\left(\mathrm{PL}_{\mathrm{sm}}\right)$ and carapace width $(\mathrm{CW})$, with their respective relative growth equations ( $\mathrm{A}=$ males; $\mathrm{B}=$ females $)$.

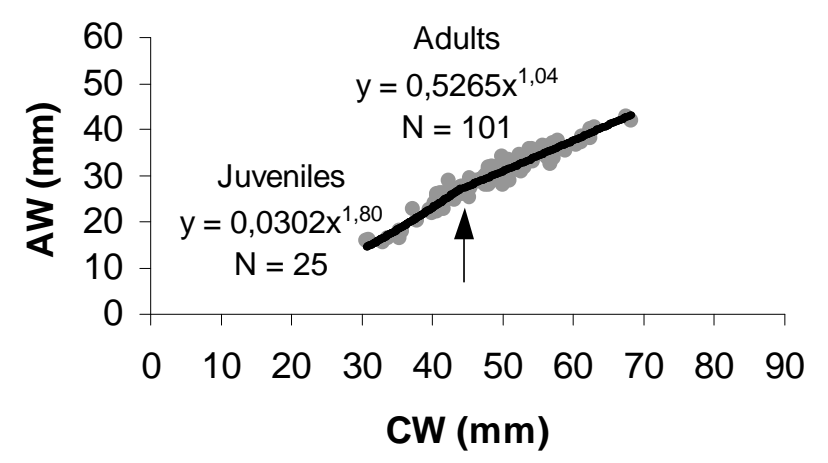

Figure 4 - Ucides cordatus (Linnaeus, 1763). Dispersion graph for the biometric relationship between abdomen width $(\mathrm{AW})$ and carapace width $(\mathrm{CW})$ for females, with their respective relative growth equations.

\section{DISCUSSION}

A differentiated growth pattern between the two sexes, presented by the carapace length and the cheliped propodus variables, indicated that its relationship with the carapace width denoted sexual dimorphism for $U$. cordatus. According to Hartnoll (1974), the growth pattern variation seemed to be adaptive, resulting in beneficial changes for the organism. The relationship CL x CW was of a negative allometry for males 
and isometric for females, indicating that, having both the same size $(\mathrm{CW})$, the internal volume was smaller in males. This pattern would be a consequence of production and differential stocks of gametes in each sex, which was known to be larger in females as already proved in other Brachyura (Weber, 1994). The size of females was also pointed by Hines (1982) as the principal variable in the quantification of reproductive efficiency in crabs, confirming that a larger cephalothoracic volume characterized reproductive optimization.

Alcântara-Filho (1978), Castro (1986) and Branco (1993) also studied the relationship CL x CW for $U$. cordatus; the former two verified a larger size for males (although using $\mathrm{CL}$ as independent variable), while the latter obtained larger sizes for females. Despite this, the authors did not use the function power in the regression analyses nor did they test the allometry level. For these reasons, these authors' data could not be compared with the results obtained in this study.

The relationship $\mathrm{PL}_{\mathrm{sm}} \times \mathrm{CW}$ did not show a difference in the growth rate during the ontogeny, despite evidencing sexual dimorphism for the species, with isometry for females and positive allometry for males. The heterochely, which consists of size difference, form and function of the chelipeds, results in a sexual dimorphism perceptible in the morphometry analyses (Hartnoll, 1982). This is proved mainly by the study on the growth rate of the chelar propodus during the ontogeny in a comparison of the allometry degree of this variable between the chelipeds of each sex. $U$. cordatus heterochely has been studied before by Santos and Mendes (1982), who verified that the chelipeds' laterality presented a similar probability, differing from most Brachyura's pattern where the right cheliped was usually bigger (Abby-Kalio and Warner, 1989).

In crabs the existence of distinct growth between the development phases was revealed by the analysis of the relationships $\mathrm{PL}_{\mathrm{lg}} \times \mathrm{CW}$ (males) and $\mathrm{AW} \times \mathrm{CW}$ (females). Males showed a more pronounced growth of the larger cheliped in the adult phase, while females, whose abdominal width showed a higher growth rate, in the juvenile phase (Hartnoll, 1974, 1978, 1982). U. cordatus fitted this pattern although the relationship $\mathrm{PL}_{\mathrm{lg}} \times \mathrm{CW}$ could not always be used to distinguish young males from adult ones. This was verified for different Portunidae species such as the Ovalipes catharus by Davidson and Marsden (1987),
Charybdis natator by Sumpton (1980), Necora puber by González-Guirriarán and Freire (1994), Liocarcinus depurator by Muiño et al. (1999) and for the Grapsidae Pachygrapsus transversus by Flores and Negreiros-Fransozo (1999).

The Portunidae's chelipeds did not show high allometry rates of the larger cheliped. This was probably because their species had a capacity to swim short distances (Davidson and Marsden, 1987; Abelló, et al., 1990), although this type of motility could be harmed in the event of a high allometry degree on their somites. Such a feature would explain the inequality in the growth pattern of the larger cheliped among juveniles and adults.

For $U$. cordatus males, the relationship $\mathrm{PL}_{\mathrm{lg}} \mathrm{x} \mathrm{CW}$ showed isometry in young males and positive allometry in adults, with a smaller allometry level in females. This resulted in larger chelipeds on males, which had been attributed to reproductive, territorial and combat behavior (Hartnoll, 1974, 1982).

The relationship AW x CW evidenced a difference in growth pattern among young females (positive allometry) and adults (isometry). The growth rate reduction in adult phase allowed the adequate abdominal proportion for protection to the incubated eggs in pleopods, which avoided a reproductive efficiency reduction and difficulty in locomotion (Hartnoll, 1982). Similar size verified in $U$. cordatus males' and females' morphologic maturity was certainly related to its semiterrestrial behaviour features with up to a five-hour-mating, which occurred with both partners during intermoult (Hartnoll, 1969). On the other hand, male aquatic Brachyura at maturity was bigger than the female, which favored the formation of couples with males having advantage on females at mating time in post-moult (Jivoff, 1997). In this case, bigger males could provide a female with further protection, as pointed out for Arenaeus cribrarius by Pinheiro and Fransozo (1998, 1999). In Southern and South-eastern Brazil, the capture and commercialization of $U$. cordatus has been legalized by Ibama regulation 122/2001, a result of a participatory management process coordinated by Cepsul/Ibama. It basically establishes: (1) a minimum capture size of $60 \mathrm{~mm}$ for carapace width; (2) a three-month protection (October $1^{\text {st }}$ to December $20^{\text {th }}$ ) during the females' gonadal mating/maturation period; (3) prohibition of any kind of trap for capture; and (4) prohibition of the capture of ovigerous females at any time of the year. The adoption of a minimum size for capture 
in the legislation intends to protect the population stock of the species, providing the individuals with the opportunity for reproduction at least once before being available for fishing (Bowen, 1971). As the sizes obtained for this study were below those established by the regional regulation, its purpose was valid as a conservational instrument for the fishing ground to which it was meant for.

\section{ACKNOWLEDGEMENTS}

We express special gratitude to Odair for his help during the catch. This research was supported by CAPES.

\section{RESUMO}

Análises de crescimento relativo foram realizadas para exemplares de Ucides cordatus, coletados mensalmente durante um ano na Baía das Laranjeiras, sul do Brasil. O comprimento da carapaça, o comprimento do própodo dos quelípodos e a largura do abdome tiveram suas medidas relacionadas à largura da carapaça, para verificar o dimorfismo sexual e o tamanho na maturidade morfológica. $\mathrm{O}$ comprimento da carapaça e do própodo dos quelípodos maior e menor apresentaram padrões de crescimento diferenciados entre os sexos, indicando serem caracteres sexuais secundários para a espécie. $\mathrm{O}$ programa MATURE II indicou os tamanhos de 44 e $43 \mathrm{~mm}$ de largura de carapaça para a maturidade sexual morfológica de machos e fêmeas, respectivamente.

\section{REFERENCES}

Abby-Kalio, N. J. and Warner, G. F. (1989), Heterochely and handedness in the shore crab Carcinus maenas (L.) (Crustacea: Brachyura). Zool. J. Linn. Soc., 96, 19-26.

Abelló, P.; Pertierra J. P. and Reid D. G. (1990), Sexual size dimorphism, relative growth and handedness in Liocarcinus depurator and Macropipus tuberculatus (Brachyura, Portunidae). Scient. Mar., 54, 195-202.

Alcântara-Filho, P. (1978), Contribuição ao estudo da biologia e ecologia do caranguejo-uçá Ucides cordatus cordatus (LINNAEUS, 1763) (CRUSTACEA, DECAPODA, BRACHYURA), no manguezal do Rio Ceará (Brasil). Arq. Ciên. Mar, 18, 1-41.
Bowen, B. K. (1971), Management of the Western Rock Lobster (Panulirus longipes cygnus, George). Proc. Indo-Pacific Fish. Coun., 14, 139-154.

Branco, J. O. (1993), Aspectos bioecológicos do caranguejo Ucides cordatus (Linnaeus, 1763) (Crustacea, Decapoda) do manguezal do Itacorubi, Santa Catarina, BR. Arq. Biol. Tecnol., 36, 133-148.

Castro, A. C. L. (1986), Aspectos bio-ecológicos do caranguejo-uçá, Ucides cordatus cordatus (LINNAEUS, 1763), no estuário do Rio dos Cachorros e Estreito do Coqueiro, São Luís - MA. Bol. Lab. Hidrob. São Luís, 7, 7-26.

Comeau, M. and Conan G. Y. (1992), Morphometry and gonad maturity of male snow crab, Chionoecetes opilio. Can. J. Fish. Aquat. Sci., 49, 2460-2468.

Conan, G. Y. and Comeau M. (1986), Functional maturity and terminal molt of male snow crab, Chionoecetes opilio. Can. J. Fish. Aquat. Sci., 43, 1710-1719.

Costa, R. S. (1979). Bioecologia do caranguejo-uçá, Ucides cordatus (Linnaeus, 1763) - Crustáceo, Decápode - no Nordeste Brasileiro. Bol. Cear. Agron., 20, 1-74.

Davidson, R. J. and Marsden I. D. (1987), Size relationships and relative growth of the New Zealand swimming crab Ovalipes catharus (White, 1843). J. Crust. Biol., 7, 308-317.

Fausto-Filho, J. (1968), Crustáceos decápodos de valor comercial ou utilizados como alimento no nordeste brasileiro. Biol. Soc. Cear. Agron., 9, 27-28.

Flores, A. and Negreiros-Fransozo M. L. (1999), Allometry of the secondary sexual characters of the shore crab Pachygrapsus transversus (Gibbes, 1850) (Brachyura, Grapsidae). Crustaceana, 72: 1051-1066.

González-Gurriarán, E. and Freire J. (1994), Sexual maturity in the velvet swimming crab Necora puber (Brachyura, Portunidae): morphometric and reproductive analyses. ICES J. mar. Sci., 51, 133-145.

Haefner Jr., P. A. (1990), Morphometry and size at maturity of Callinectes ornatus (Brachyura, Portunidae) in Bermuda. Bull. Mar. Sci., 46, 274-286.

Hartnoll, R. G. (1969), Mating in Brachyura. Crustaceana, 16, 161-181.

Hartnoll, R. G. (1974), Variation in growth pattern between some secondary sexual charaters in crabs (Decapoda, Brachyura). Crustaceana, 27, 131-136.

Hartnoll, R. G. (1978), The determination of relative growth in Crustacea. Crustaceana, 34, 281-293.

Hartnoll, R. G. (1982), Growth. In - The Biology of Crustacea. Embriology, Morphology, and Genetics, ed. L. G. Abele. New York, Academic Press, 2. pp. 111-196.

Hines, A. H. (1982), Allometric constraints and variables of reproductive effort in brachyuran crabs. Mar. Biol., 69, 09-320.

Huxley, J. S. (1950), Relative growth and form transformation. Proc. R. Soc. London, 137, 465-469. 
IBAMA (1994), Lagosta, Caranguejo-Uçá e Camarãodo-Nordeste. Coleção Meio Ambiente. Série Estudos - Pesca, v. 10, Ibama/Brasília, 190 pp.

Jivoff, P. (1997), Sexual competition among male blue crab, Callinectes sapidus. Biol. Bull., 193, 368-380.

Knuckey, I. A. (1996), Maturity in male mud crabs, Scylla serrata, ans the use of mating scars as a functional indicator. J. Crust. Biol., 16, 487-495.

Muiño, R.; Fernández L.; González-Gurriarán E.; Freire J. and Vilar J. A. (1999), Size at maturity of Liocarcinus depurator (Brachyura: Portunidae): a reproductive and morphometric study. J. Mar. Biol. Ass. U.K., 79, 295-303.

Paul, A. J. and Paul J. M. (1995), Moulting of functionally mature male Chionoecetes bairdi Rathbun (Decapoda: Majidae) and changes in carapace and chela measurements. J. Crust. Biol., 15, 686-692.

Pinheiro, M. A. A. and Fransozo A. (1993), Relative growth of the speckled swimming crab Arenaeus cribrarius (Lamarck, 1818) (Brachyura, Portunidae), near Ubatuba, state of São Paulo, Brazil. Crustaceana, 65, 377-389.

Pinheiro, M. A. A. and Fransozo A. (1998), Sexual maturity of the speckled swimming crab Arenaeus cribrarius (Lamarck, 1818) (Decapoda, Brachyura, Portunidae), in the Ubatuba littoral, São Paulo state, Brazil. Crustaceana, 71, 434-452.

Pinheiro, M. A. A. and Fransozo A. (1999), Reproductive Behavior of the swimming crab Arenaeus cribrarius (Lamarck, 1818) (Crustacea, Brachyura, Portunidae) in captivity. Bull. Mar. Sci., 64, 243-253.

Sampedro, M. P.; González-Gurriarán E.; Freire J. and Muiño R. (1999), Morphometry and sexual maturity in the spider crab Maja squinado (Decapoda: Majidae) in Galicia, Spain. J. Crust. Biol., 19, 578-592.

Santos, M. C. F. and Mendes E. G. (1982), Biometric studies and mechanical advantages in the dimorphic chelae of the mangrove crab, Ucides cordatus. Bol. Fisiol. Anim. (São Paulo), 6, 143-150.
Somerton, D. A. (1980), A computer technique for estimating the size of sexual maturity in crabs. Can. J. Fish. Aquat. Sci., 37, 1488-1494.

Somerton, D. A. (1981), Regional variation in the size and maturity of two species of tanner crab (Chionoecetes bairdi and C. opilio) in the eastern Bering Sea, and its use in defining management subareas. Can. J. Fish. Aquat. Sci., 38, 163-174.

Somerton, D. A. and Macintosh R. A. (1983), The size at sexual maturity of the blue king crab, Paralithodes platipus, in Alaska. Fish. Bull. U.S., 81, 621-628.

Sumpton, W. D. (1990), Morphometric growth and fisheries biology of the crab, Charybdis natator (Herbst) in Moreton Bay, Australia (Decapoda, Brachyura). Crustaceana, 59, 113-120.

Weber, L. I. (1994), Determinación de dimorfismo y talla de madurez sexual mediante la equación alométrica en una población de Cancer plebejus Poeppig, 1836 (Decapoda, Brachyura) del sur de Chile. Cah. Biol. Mar., 35, 177-192.

Received: September 30, 2003; Revised: January 30, 2004; Accepted: July 07, 2004. 